Contents List available at VOLKSON PRESS

Intelligent Computing and Information Engineering (ICIE )

DOI : http://doi.org/10.26480/icie.01.2017.133.135

Journal Homepage: : https://www.intelcomp-design.com/

\title{
ON THE INFLUENCE OF CHINA-ENGLISH BY THE EXAMPLE OF KUNG FU PANDA'S SUBTITLE TRANSLATION
}

Junyan Liu

Wuhan Donghu University, Wuhan, Hubei, China

*Corresponding author Email: junyanliu2004@163.com

This is an open access article distributed under the Creative Commons Attribution License, which permits unrestricted use, distribution, and reproduction in any medium, provided the original work is properly cited

\section{ARTICLE DETAILS}

\section{Article History:}

Received 12 May2017

Accepted 12 July 2017

Available online 14 September 2017

Keywords:

China-English, influence, Kung Fu

Panda, subtitles translation.

\section{ABSTRACT}

In the translation of the mass culture media of the film, the use of "China-English" can easier achieve the purpose of cultural propaganda and communication. This article mainly focuses on the analysis of subtitles translation on Kung Fu Panda, China-English characteristics and the translation strategies of China-English in Kung Fu Panda subtitles translation. In the end, it is concluded that with the strengthening comprehensive national strength of China, ChinaEnglish would be more widely accepted and more frequently used around the world.

\section{INTRODUCTION}

With the quick strengthening of the comprehensive national strength, Chinese influence is far-reaching throughout the world [1]. The language in the movie is also very special, for its characterized by many Chinese-flavored objectives. This paper aims at offering a concrete analysis of China-English influence, and making contributions to the on-going translation of film subtitles translation.

\section{THE CONTRAST BETWEEN CHINA-ENGLISH AND CHINGLISH}

China-English is adapted to express characteristics of China while Chinglish is usually used to simply translate Chinese to English but fail to follow the rules of Standard English [2]. China-English is able to transmit cultural references that Chinese speakers would like to communicate. Because sometimes it is hard to find strict equivalents in other varieties of English in the translation between Chinese and English, expressions such as one country, two systems( 一 国 两制), one China policy (一个中国), and special economic zone(经济特区) are uniquely appropriate regarding what is happening in China. But for Chinglish, it is often found in translating Chinese to English, expressions such as no three to four(不三不四), go past, no mistake past (走过路过，不要错过 ) and heart flower angry open(心花怒放) and etc. All these expressions did not follow the rules of standard English, so native English speakers cannot catch their exact meanings.

In conclusion, with new vocabulary and structure, China-English is normative English and it will increase its strength with further publicity to the outside world, while Chinglish is improper use of English due to poor knowledge to the English language and culture and may hinder the communication with other cultures [3]. In future, Chinglish would probably diminish or even disappear with the deepening of culture communication between China and other countries while China-English would be more widely accepted and more frequently used around the world [4].

\section{THE ANALYSIS OF SUBTITLES TRANSLATION ON KUNG FU PANDA}

\subsection{The Introduction of the Movie Kung Fu Panda}

Po (阿宝) was a fat panda and he was clumsy in movement. He was an honest fan of Kung fu, and dreamed to be one of a greatest Kung fu masters to keep the Peace Valley in peace forever. While the worst thing happened to the Peace Valley, their greatest enemy, a leopard called Tai Lung who wanted to be the Dragon Warrior, had escaped from the jail and would take revenge to Master Shifu. All citizens in the valley fell in big fears. He showed his talents in Kung Fu and finally defeated the leopard. Finally The Peace Valley was peaceful again.

\subsection{The Connection Between Kung Fu Panda and China-English}

\subsubsection{The Translation of People's Names}

In the movie, there are many funny roles. Po (阿宝) is the name everyone calls the fat panda, whose pronunciation is very close to “baobao (宝宝)”, the first name to a new born baby in China. Chinese people think the interesting plots are some things that happen to our daily lives, so they give their care and love to the fat panda as much as to their own children. English speakers call their children "baby" "honey" rather than "baobao". The reflecting culture in this movie, based on Chinese Kung fu and the panda, which makes Chinese people too familiar with. So "Po" let Chinese audiences apt to love and admit it.

\subsubsection{The Translation of Places}


Here are three Chinese characterized places: The Jade Palace(翡翠宫), the Sacred Hall of Warrior(武士圣殿) and Demon Mountain(恶魔山).

First is the Jade Palace. It is a place where the Furious Five and Master Shifu live and practice Kung fu. Jade in China is regarded as a kind of lofty spirit, the proverb "be pure as jade and clean as ice"(玉洁冰清) can show such meaning. So the Jade Palace is a place where only those great persons whom many people express their admiration to, can live in.

Second is the Demon Mountain. After hearing the name, people can know where and what kind of place it is. When it is mentioned, an allusion of exact position would be in everyone's mind.

\subsubsection{The Translation of Other Special Words}

Some words are very interesting in Kung Fu Panda, because they are really fulfilled with Chinese flavors.

The example is “Wuxi Finger Hold” (弹指神功) that Master Shifu had used to hold the panda's fingers on the first day when Po was in the Jade Palace.

"Wuxi" is used here which means "Wushi"(武士) but not "warrior", because a warrior is "a person who fights in a battle or war" [2]. Because the pronunciation of Wuxi is much closer to Wushi, so the former one chosen here is reasonable, as it can make not only Chinese people but also English speakers and learners to know Chinese Kung fu and China-English, although the two words contain an identical meaning.

\section{THE ANALYSIS OF CHINA-ENGLISH CHARACTERISTICS}

\subsection{One of Performance Varieties}

China-English is one branch of world's English. In other word, it is a kind of language variant. B.B. Cachru, a famous America social linguist, classified all the English varieties into two: one is institutionalized variety, and the other is performance variety (Pan 76). The aim and function of China- English is to communicate with non-Chinese speakers in the areas of politics, economics and culture. But it is hardly used among all Chinese people. So according to the above classifying ways, China-English belongs to the category of performance variety rather than the institutional one.

\subsection{One of Languages Based on Normative English}

Chinglish is a malformation. It is only an inter language which embodies many pragmatic mistakes that occur to Chinese students in learning course and application process. Their basic pronunciation, spell, application and grammars are apparently big mistakes. Tan Yumei thought these mistakes should be in the category of Chinglish, absolutely not in the category of China-English (Tan 4). For instance, “His head is very clever” (他的头脑很联明), “My stomach is hungry" (我肚子饿了), both two sentences have no grammatical mistakes, but they don't follow the English-speaking ways. The native speakers would say "He is very clever" and "I'm hungry" rather than the above examples.

\subsection{One of Languages to Express Chinese-flavored Objectives}

Premier Wen Jiabao proposed "A package of plans" to meet the challenges of the financial crisis in the government report on the second conference of eleventh session of National People's Congress on March $5^{\text {th }}, 2009$. But to foreigners, who can understand what "the package of plans" mean without the background of the conference? Chinese people could easily to know that the plans are some measures to be taken to save and develop Chinese economic situation when meeting the world financial crisis. Non-Chinese speakers would never think plans and measures can be put into a package.

\subsection{One of a Developing System}

With a high speed development, China-English, a Chinese characterized English variety, has been admitted by an increasing numbers of people. Its existence could not be parted its developing rationality and inevitability away. China-English is a developing system. The appearing of China-English is not by accident, but a certain phenomenon (Kirkpatrick and Xu 288). It has experienced a decade development and practice.

\section{THE TRANSLATION STRATEGIES OF CHINA-ENGLISH IN KUNG FU PANDA SUBTITLES TRANSLATION}

\subsection{Domestication Translation in Kung Fu Panda}

Domestication translation regards target readers as the starting point and the destination point, which tries to use the language forms, cultural traditions and customs of target languages and so on. The film Kung Fu Panda is a Hollywood blockbuster, focusing on showing a "American dream" spirit, that is, regardless of personal conditions, as long as people keep continuous efforts and never give up, they will be able to achieve their dreams. Meanwhile, many Chinese elements has been integrated into this film, such as panda, Kung fu, temple fair, fireworks, mantis boxing, master shifu etc, those are the cultural background that Chinese audience know well.

For example, “The mark of a true hero is humility”, which can be translated as “真英雄虚怀若谷, 且以谦卑为怀”, “enough talk! let's fight” can be translated as “少废话! 拿命来”, “I have had a vision of Tai Lung will return”, can be translated as “我感到黑豹太郎要重出江湖”(Chen 7), which accord with the expression ways and language habits of Chinese audience.

In addition, in the film of Kung Fu Panda, there are so many subtitles with traditional Chinese philosophy. So when we translate these words, we cannot use the simple literal translation, but use domestication translation to represent the deep meaning of words. In the film subtitles translation, with not being limited rigidly by the original forms and also adjusting the original structure appropriately, China-English can make film subtitles translation more vivid and concise, lively and animated. That's why Kung Fu Panda can be easily accepted by the audiences.

\subsection{Foreignization Translation in Kung Fu Panda}

Foreignization translation regards source readers as the starting point and the destination point, which tries to use the language forms, cultural traditions and customs of source languages to make subtitles translation full of exotic cultural colors.

In the film subtitles translation, people can choose flexible and various translation methods, so that the audience can understand exotic culture and customs more. In the film of Kung Fu Panda, 虎拳,鹤拳, 猴拳,螳螂拳, with profound Chinese cultural connotation, is an important part of Chinese martial arts culture. If these words are translated as "tiger" "crane" "monkey" and "Mantis", it cannot show the cuteness of The Furious Five. Also, the sentence "yes, look at this, Shifu, I cannot make it blossom when it suits me...but you will get a peach”, this sentence can be translated by literal translation method as “是的, 看看这棵 
树, 我不能随心所欲地令其开花......可你只能得到桃子”. The subtitle of this sentence happened when Master Shifu and Po were enjoying their foods in the tree, also when peach seedlings were growing up. At the last, the audience can easily understand the film subtitles information.

All in all, the using of foreignization translation strategy in the film of Kung Fu Panda can make the Chinese audiences easier to know what the film expresses. Also overseas audiences can study and know more Chinese profound traditional culture. Foreignization translation can reproduce the expression way of the original text, which not only shows exotic source language, but enrich and improve the translation (Bassnett 15). So people can know other countries' culture by reading the subtitles translation. Besides, People can view the influence of China-English from the subtitles translation of Kung Fu Panda.

\section{CONCLUSION}

China-English is very extensively used in China in recent years, including in some important international occasions. Its existence is certainly a contribution to the language of English. All languages have their disadvantages, so none of them can wholly, objectively and appropriately reflect every kind of culture in the world. English, which has a huge vocabulary and a strong innovation, is included in. Moreover, Chinese culture is extensive and profound, no other foreign language has the capability to totally hold it. The Chinese-flavored English also has largely enriched English vocabulary, widened its meanings, strengthened its power of expression and expanded its influence in both China and her culture.

\section{ACKNOWLEDGMENT}

This research is one of the results of the project of "The Study of the English Translation of Chinese Classics from the Perspective of Translation EthicsTake the Translation of Chu Cultural Treasure Chu Ci as an Example". This project is financially supported by Wuhan Donghu University, Wuhan, Hubei, China and The Humanities and Social Science Foundation of Hubei Provincial Department of Education 2016.

\section{REFERENCES}

[1] Susan, B. 2001. Translation Studies (Third Edition). Shanghai: Shanghai Foreign Language Education Press.

[2] Hornby, A.S. 2004. Oxford Advanced Learner's English-Chinese Dictionary, Sixth Edition. Oxford: Oxfords University Press.

[3] Kirkpatrick, A., Zhichang, X. 2002. Chinese Pragmatic Norms and China English. World Englishers, 21 (2), 269-79.

[4] Zhangxian, P. 2005. Linguistic and Cultural Identities in Chinese Varieties of English [M]. Beijing: Peking University Press. 